\title{
ECOLOGICAL-FAUNISTIC ANALYSIS \\ OF PARASITES OF FISH LARVAE AND FRY \\ IN THE LOWER REACHES OF THE DNIEPER
}

\section{Olifirenko V. V., Kornienko V. O.}

\section{INTRODUCTION}

At present, substances that cause intoxication and provoke various forms of a toxic process, not only of the organism, but also of biological systems, like various forms of parasitic organisms, have become an integral factor of the external environment for living organisms, including aquatic organisms, in particular for fish. This issue is very acute in the conditions of Hydro Ecosystems of Ukraine, which is reflected in the annual National Reports on the state of the environment ${ }^{1}$. Pollution with heavy metals, pesticides, petroleum hydrocarbons, surfactants and other chemical compounds worsens the physiological state of aquatic organisms, and, as a consequence, limits the bioproductive potential of aquatic ecosystems ${ }^{2}$.

As a result of progressive environmental pollution in the lower reaches of the Dnieper, a rather critical ichthyopathological situation has developed. It is caused by a variety of biological and environmental factors. First of all, this is due to the fact that the resistance of fish to the effects of parasites is determined not only by their size, age, sex and

1 Національна доповідь про стан навколишнього середовища Херсонської області. Київ : Вид. Раєвського, 2018. 60 с.

2 Пилипенко Ю.В., Оліфіренко В.В., Корнієнко В.О., Поліщук В.С, Довбиш О.Е., Лобанов I.А. Екологічні передумови раціонального ведення рибного господарства Дніпровсько-Бузької гирлової області. Херсон : Видавець Грінь Д.МС., 2013;

Hubanova, N., Horchanok, A., Novitskii, R., Sapronova, V., Kuzmenko, O., Grynevych, N.,. Prisjazhnjuk, N, Lieshchova, M., Slobodeniuk, O., Demyanyuk, O. Accumulation of radionuclides in Dnipro reservoir fish. Ukrainian Journal of Ecology, 2019, 9(2), p. 228;

Fedonenko, O., Yesipova, N., Sharamok,T. The accumulation of heavy metals and cytometric characteristics features of red blood cells in different ages of carp fish from Zaporozhian Reservoir. International Letters of Natural Sciences, 2016. Vol. 53, p. 72. https://doi.org/10.18052/www.scipress.com/ILNS.53.72 
other quality indicators, but also by the physiological state of the fish, and also depends on the level of negative impact on the fish of critical environmental factors.

The parasite fauna of fish directly depends on the nature, type and other ecological features of the reservoir. Modern studies of the distribution of various factors affecting parasite communities in the host fish system have divided them into two groups: biotic and abiotic ${ }^{3}$. Among biotic factors, many authors consider the most important factors such as the age and size of the host, the size of the host and the size of parasites, the specificity of the host, the diet of the host and its sex, as well as their influence on the number and distribution of parasites. The abiotic component lies in terms of seasonality and changes in the main physical and chemical indicators of water, both under the influence of the anthropogenic component and as a result of global climate change ${ }^{4}$.

The analysis of the peculiarities of the distribution of parasites in fish with different diets shows how dependent are the differences in the feeding behavior of fish and the degree of aggregation of helminths among the hosts. At the same time, parasitic organisms whose life cycle is not associated with the food chain, such as ectoparasites or three-host species, can adapt to the habitat and biological characteristics of the host. Each type of reservoir has its own specific parasite fauna. It depends on the physicochemical and hydrological regime of the ecosystem, the level of its trophicity, on the presence or absence of final and intermediate hosts, that is, on the constellation of abiotic and biotic factors.

Even minor changes in the ecological regime of water bodies can affect the freely existing fauna and through it or directly - on the fauna of parasites. In this case, the dynamic processes of development of the parasite fauna can directly affect the composition of the ichthyofauna, including its commercial part. A number of pathogens pose a danger to human health: diphyllobothrias, opisthorchids, pseudamphistomas, paragonimi, etc.

The dynamics of the composition of the parzitofauna caused by changes in the climatic and ecological nature necessitate constant monitoring. This formed the basis for the special studies conducted.

${ }^{3}$ Беэр С.А. Роль патогенности паразитов в эволюции органического мира. Успехи общей паразитологи. 2003. Т. 44. С. 65-66

4 Iyaji, F., Etim, L., \& Eyo, J. (2010). Parasite assemblages in fish hosts. Bio-Research, 7(2), 561-570 


\section{The problem's prerequisites emergence and the problem's formulation}

Significant disadvantage of modern fisheries management is a general decrease in fish resistance, which creates positive conditions for the emergence of massive epizootics. The latter lead to a deterioration in the general physiological state of fish, a decrease in the growth potential and mass accumulation, and often to their mass death.

Currently, polyetiological diseases have come to the fore, where each of the active pathogenic organisms alone does not always provoke a disease, and with a combined effect, the likelihood of its occurrence increases. This is especially evident against the background of increasing pollution of natural water bodies.

The main task of the presented studies was to conduct an ecologicalfaunistic analysis of parasites of larvae and fry of the main commercial fish species in the lower reaches of the Dnieper, to determine the degree of development of the parasite fauna in the studied species.

Selection of ichthyological and ichthyopathological samples in 2018-2020 carried out in the flooded reservoirs of the lower reaches of the Dnieper, its branches and the main course. Sterlet juveniles were examined at the State Enterprise Dneprovskiy sturgeon fish breeding factory.

Epizootic research was carried out three times a year: in early spring, in mid-summer, and in late autumn, in accordance with well-known recommendations 5 .

Studied 14 taxa of the species level, parasites and pathogens in natural water bodies. 11 fish species from 4 families have been studied. The larvae and fry of the following fish species were examined: bream (Abramis brama), starlet (Acipenser ruthenus), silver bream (Blicca bjoerkna), roach (Rutilus rutilus), reddish (Rutilus heckelii), carp (Cyprinus carpio), ide (Leuciscus idus), rudd (Scardinius erythrophthalmus), pike (Esox lucius), zander (Sander lucioperca), perch (Perca fluviatilis).

Fish fry were examined immediately after hatching from eggs at the prelarva stage. During the first month, the larvae were examined every

5 Matvjenko N, Buchatsky L, Rud Yu. Methodological recommendations on laboratory diagnosis of fish diseases. Kyiv, IRG NAAN. 2009;19 p.;

Пилипенко Ю.В., Шевченко П.Г., Цедик В.В., Корнієнко В.О. Методи іхтіологічних досліджень: Навчальний посібник. Херсон: Олді-Плюс, 2017. $432 \mathrm{c}$. 
five days, at the fry stage - after 7-10 days. The species belonging of the larvae of cyprinids was determined by the method based on the calculation of the ratio of segments and vertebrae ${ }^{6}$.

With the onset of the juvenile period of fish life and the appearance of definitive characters, it was determined in the same way as for adult fish.

The work on the identification of parasites was carried out by the method of complete parasitological autopsies, taking into account all parasites belonging to all systematic groups. Fixation and cameral processing were carried out by the usual methods adopted in parasitological studies. The collected parasites were fixed with $70 \%$ ethanol for subsequent identification. The parasites were stored as permanent and temporary preparations and examined using light microscopy to identify species. Morphological identification of parasites from specimens of mucus from gills, skin, and fins was carried out under a microscope with a magnification of $10 \times 40$.

The periods of development of juveniles were determined on the basis of generally accepted recommendations in ichthyology ${ }^{7}$. A standard ichthyopathological examination of fish was carried out to identify parasites, according to Buchmann ${ }^{8}$.

\section{Analysis of parasites of fish larvae and fry in the lower reaches of the Dnieper}

In the course of special studies, 3144 specimens were examined. fish. Of the total number of fry examined, 1,822 individuals were infected with parasites, which is $58.5 \%$. The found parasites belong to nine systematic groups: Protozoa - 28.3\%; Trematodes - 31.9\%; Monogeneans - 16.9\%; Cestodes $-3.0 \%$; Nematodes $-1.3 \%$; Scrapers 0.5\%; Leeches - 0.03\%; Crustaceans - 4.5; Mollusks - 0.5 (Table 1).

A total of 91 species of parasites were found. The fauna of parasitic protozoa in fish larvae and fry is represented by 26 species. Basically, these are ciliary ciliates. Representatives of this class of protozoa appear in fish larvae immediately after hatching from eggs.

6 Коблицкая А.Ф. Определитель молоди пресноводных рыб. Москва : Легкая промышленность, 1981. 208 с

${ }^{7}$ Пилипенко Ю.В. та інш. Приведено вище.

8 Buchmann K. An introduction to practical methods in fish parasitology. Classical and molecular techniques. Denmark, Frederiksberg: Biofolia Press, 2007. $130 \mathrm{p}$. 


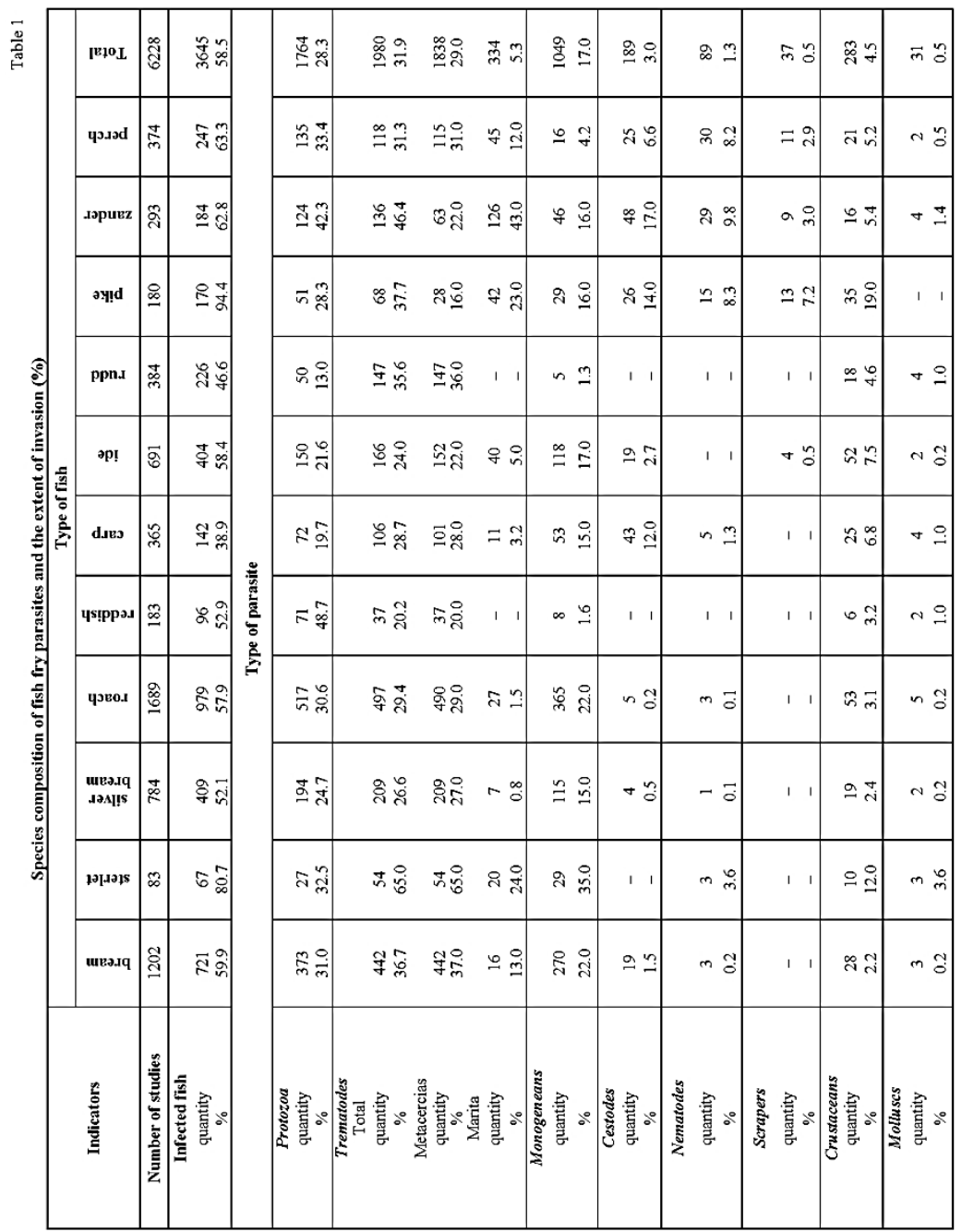


This period in development is characterized by the fact that the transition of the larvae to active feeding has not yet been completely completed and they are inactive, single specimens of one or two species of trichodinas and apiosomes appear on them (mainly Triohodina nigra, Triohodina mutabilis, Apiosoma minutum ).

During the first month of fish life, the extensiveness of invasion increases from 3.3 to $34.5 \%$, and the number of parasite species increases from one or two to 5-17. A similar picture of the intensity of invasion is observed in the larvae of the early stages of development single individuals of parasites usually settle on the surface of the body.

In the future, the number of parasites on one fish gradually increases and infusoria colonize fins and gill petals. The maximum infection with protozoa was observed in late May - early June (34.5 and 44.6\%) (Table 2).

Trematodes are also one of the numerous groups of parasites (25 species), of which 12 species are found at the marita stage. The degree of eruption of juvenile fish with trematode marites is insignificant $(5.3 \%$, the intensity of invasion is $1-5$ specimens). Infection of fish with maritas of trematodes is carried out mainly through invertebrates - intermediate hosts, therefore fish become infected only with intensive feeding of invertebrates. Thus, the time of infection of fish with maritas of trematodes is mainly determined by two factors: on the one hand, the moment when the larva of the trematode in the intermediate host reaches the invasive stage, and on the other, the nature of feeding of juvenile fish. The second factor is well illustrated in the analysis of the parasite fauna of juvenile zander, perch, and pike. Juveniles of pike perch and pike pass to predation at the early stages of postembryogenesis. In the parasite fauna, this is reflected in the fact that at this time they are intensively infested with marites of the trematodes Bucephalus polymorphus, Rhipidocotyle illense, whose metacercariae parasitize juvenile cyprinids. Perch fry, remaining planktophagous for a long time, eat large numbers of crustaceans Daphnia pulex, Simonocephalus expinosus, Eurycercus lamellatus, Notodroma monacha, which are intermediate hosts for the trematode Bunodera luciopercae. 
Table 2

Extensiveness of infection of fish larvae and fry with parasites from various taxonomic groups (\%)

\begin{tabular}{|c|c|c|c|c|c|c|c|c|c|c|c|}
\hline \multirow[b]{2}{*}{ Type of parasite } & \multicolumn{11}{|c|}{ Host and extensiveness of invasion } \\
\hline & 嘅 & 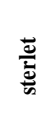 & 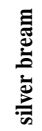 & 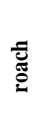 & $\frac{\bar{c}}{\overline{\underline{n}}}$ & 휼 & $\stackrel{\mathscr{2}}{.}$ & 플 & 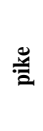 & 莺 & 惡 \\
\hline \multicolumn{12}{|c|}{ Protozoa } \\
\hline Cryptobie sp. & 0.08 & & 0.1 & 0.06 & & & & & & & \\
\hline $\begin{array}{c}\text { Costis necatrix } \\
\text { Hennequy, } 1884\end{array}$ & 0.09 & & 0.1 & & & & & & & & 90.8 \\
\hline $\begin{array}{c}\text { Himeros cerpelli } \\
\text { Leger et } \\
\text { Stankovsch, } 1921\end{array}$ & & & & & & 9.6 & & & & & \\
\hline$\frac{\frac{\text { Myxidium }}{\text { lieberkuhni }}}{\text { Butschli, } 1882}$ & & & & & & & & & 8.3 & & \\
\hline $\begin{array}{l}\text { Chloromyxum } \\
\text { fluviatile } \\
\text { Thelohan,1892 }\end{array}$ & 0.5 & & & 0.8 & & & & & & & \\
\hline Myxobolus sp. & 0.03 & & 0.1 & & & & & & & & \\
\hline $\begin{array}{c}\text { Hunnequya } \\
\text { psorospermica } \\
\text { Thelohan,1895 }\end{array}$ & & & & & & & & & 0.2 & & \\
\hline $\begin{array}{c}\text { Thelohanellus } \\
\text { pyriformis } \\
\text { Thelohan, } 1892\end{array}$ & & & & 0.1 & & & 0.2 & & & & \\
\hline $\begin{array}{c}\text { Hemiophrys } \\
\text { branchierum } \\
\text { (Weinrich,1925 }\end{array}$ & & & & & & & & & & 0.5 & \\
\hline $\begin{array}{c}\text { Chilodonelle } \\
\text { cyprini Moroff, } \\
1902\end{array}$ & & & & & & 17 & & & & & 18.1 \\
\hline $\begin{array}{c}\text { Ichthyophthirius } \\
\text { multifiliis } \\
\text { Fouquet,1876 }\end{array}$ & 15 & 2.4 & 2.8 & 6.3 & 5.4 & 8.8 & 2.3 & & & 16.7 & \\
\hline $\begin{array}{c}\text { Trichodine } \\
\text { intermedia } \text { Lom, } \\
1960\end{array}$ & & & & & & & & & & 10.1 & 10.9 \\
\hline T. nigra Lom, 1960 & 8.4 & & 9.9 & 4.0 & & & & 9.6 & & 13.9 & 9.3 \\
\hline $\begin{array}{c}\text { T. mutabilis } \\
\text { Kosubsky et } \\
\text { Mygala, } 1968\end{array}$ & 17.2 & 30.1 & & 17.1 & & & & & & & \\
\hline $\begin{array}{c}\text { T. domerquelf. } \\
\text { acuta Lom, } 1961\end{array}$ & & & & & & & & & & 0.8 & \\
\hline $\begin{array}{c}\text { T. domerquelf. } \\
\text { esocis Lom, } 1960\end{array}$ & & & & & & & & & 0.4 & & \\
\hline $\begin{array}{l}\text { T. urinaria Dogiel, } \\
1940\end{array}$ & & & & & & & & & & & 0.2 \\
\hline $\begin{array}{c}\text { T. alburni } \\
\text { Vojtek,1957 }\end{array}$ & & & & & 09 & & & & & & \\
\hline Trichodine sp. & & & 3.7 & & & 0.7 & 1.4 & & & & \\
\hline $\begin{array}{c}\text { Trichodinella } \\
\text { percarum Dogiel, } \\
1940\end{array}$ & & & 5.2 & & & & 4.7 & 2.3 & & 12.5 & 10.6 \\
\hline
\end{tabular}




\begin{tabular}{|c|c|c|c|c|c|c|c|c|c|c|c|}
\hline $\begin{array}{c}\text { Tripartiella inciss } \\
\text { Lom, } 1939 \\
\end{array}$ & & & & & & & 0.4 & & & & \\
\hline $\begin{array}{c}\text { Apiosoma piecikols } \\
\text { Blenchard, } 1960\end{array}$ & & & & 2.7 & & & & & & 6.9 & 4.0 \\
\hline $\begin{array}{l}\text { A.campenulate } \\
\text { Timofeev, } 1960 \\
\end{array}$ & 3.3 & & 3.8 & & & & & & & 5.6 & 6.6 \\
\hline Ahiosome sp. & & & & & 7.3 & & 0.7 & & & & \\
\hline $\begin{array}{c}\text { Trichophrya } \\
\text { intermedia } \\
\text { Prost,1952 } \\
\end{array}$ & & & & & & & & & & 10.0 & 5.6 \\
\hline \multicolumn{12}{|c|}{ Trematoda } \\
\hline $\begin{array}{c}\text { Bucephalus } \\
\text { polymorphus Baer, } \\
1827\end{array}$ & & & & & & & & & 1.5 & 13.9 & \\
\hline $\begin{array}{c}\text { Rhipidocotyle illense } \\
\text { Ziegler, } 1883\end{array}$ & & & & & & & & & 4.4 & 13.2 & \\
\hline $\begin{array}{c}\text { Phyllodistomum } \\
\text { elogatum Nybelin, } \\
1926\end{array}$ & 0.1 & 1.2 & 0.2 & 0.7 & & & & & & & \\
\hline $\begin{array}{c}\text { Ph. folium Olfers, } \\
1916\end{array}$ & & & & & & & 0.7 & & 8.7 & & \\
\hline Phillodistomum sp. & & 1.2 & & & & & & & & & \\
\hline $\begin{array}{c}\text { Azygia lusii Muller, } \\
1776\end{array}$ & & & & & & & 0.7 & & 6.6 & 5.5 & \\
\hline $\begin{array}{c}\text { Allocreadsum } \\
\text { isoporum Looss, } \\
1894 \\
\end{array}$ & & & & 0.1 & & & & & & & \\
\hline $\begin{array}{c}\text { Bunodera } \\
\text { lucsopercae Muller, } \\
1776 \\
\end{array}$ & & & & & & & & & & 7.3 & 13.3 \\
\hline $\begin{array}{c}\text { Asymphylodora } \\
\text { imitans Muhling, } \\
1898 \\
\end{array}$ & 0.1 & & & & & & & & & & \\
\hline Asymphylodora sp. & & & & 0.1 & & & 0.2 & & & & \\
\hline $\begin{array}{c}\text { Pelaerochis } \\
\text { incognitus Szidat, } \\
1943\end{array}$ & & & & & & & 0.1 & & & & \\
\hline $\begin{array}{c}\text { Crowcrocaecum } \\
\text { akrjabini Iwanitzky, } \\
1928 \\
\end{array}$ & 0.7 & 20.4 & 0.5 & 0.5 & & & 1.3 & & 3.8 & 10.1 & 2.6 \\
\hline \multicolumn{12}{|c|}{ Metacercariae } \\
\hline $\begin{array}{c}\text { Bucephalus } \\
\text { polymorphus Baer, } \\
1827\end{array}$ & 7.9 & 7.2 & 8.0 & 3.2 & 5.4 & & 1.1 & 3.1 & & & \\
\hline $\begin{array}{c}\text { Rhipidocotyle illense } \\
\text { Ziegler, } 1883 \\
\end{array}$ & 3.7 & 3.6 & 3.1 & 1.2 & 0.4 & & 0.4 & 3.1 & & & \\
\hline $\begin{array}{l}\text { Tetrscotyle echinata } \\
\text { Diesing, } 1858 \\
\end{array}$ & & & & & & & 0.04 & & & & \\
\hline $\begin{array}{l}\text { T.perose-fluvistilis } \\
\text { Diesing, } 1858 \\
\end{array}$ & & & & & & & & & & & 0.04 \\
\hline $\begin{array}{l}\text { Cotylurus pilestus } \\
\text { Rud.,1819 }\end{array}$ & 1.0 & 6.0 & 0.2 & 0.06 & & & 0.7 & & & 20.0 & 16.2 \\
\hline $\begin{array}{l}\text { Dipilostum } \\
\text { spathaceum } \\
\text { Rud.,1819 } \\
\end{array}$ & 13.7 & 27.7 & 7.0 & & 6.0 & 7.4 & 3.8 & 4.9 & 6.6 & 5.0 & \\
\hline $\begin{array}{c}\text { Diplostomum } \\
\text { elavatum Nordm., } \\
1832\end{array}$ & 8.6 & 9.6 & 5.9 & 5.3 & 5.1 & & 5.3 & 3.3 & 10.1 & 3.1 & 2.6 \\
\hline
\end{tabular}




\begin{tabular}{|c|c|c|c|c|c|c|c|c|c|c|c|}
\hline $\begin{array}{c}\text { Neascus } \\
\text { brevisaudatus } \\
\text { Nordm.,1835 }\end{array}$ & & & & & & & 0.2 & & & & 0.5 \\
\hline $\begin{array}{c}\text { Posthodiplostomum } \\
\text { cuticola } \\
\text { Nordm.,1832 } \\
\end{array}$ & 13.6 & 16.8 & 9.3 & 15.9 & $\begin{array}{c}13 . \\
1\end{array}$ & 11.1 & 8.2 & 33.3 & & & \\
\hline $\begin{array}{c}\text { Neodiplostomum } \\
\text { pseudattenuatum } \\
\text { Dubois, } 1928\end{array}$ & & & & & & & & 4.9 & & & \\
\hline $\begin{array}{l}\text { Hesteromorphe } \\
\text { triloba } \text { Rud.,1819 }\end{array}$ & 2.5 & 10.8 & 0.2 & 1.0 & & & & & & & \\
\hline $\begin{array}{c}\text { Clinostomum } \\
\text { complenatum Rud., } \\
1819\end{array}$ & & & & & & & & & & & 90.03 \\
\hline $\begin{array}{l}\text { Trematoda lerva gen. } \\
\text { sp. }\end{array}$ & & & 0.2 & 0.1 & & & 2.7 & & & & \\
\hline \multicolumn{12}{|c|}{ Monogenee } \\
\hline $\begin{array}{c}\text { Dactylogyrus similis } \\
\text { Wagener, } 1909\end{array}$ & & & 0.4 & & & & & & & & \\
\hline $\begin{array}{c}\text { D.auniculatus Wedl, } \\
1857\end{array}$ & 1.0 & & & & & & & & & & \\
\hline $\begin{array}{c}\text { D. falcatus Nordm., } \\
1832 \\
\end{array}$ & 0.1 & & & & & & & & & & \\
\hline $\begin{array}{l}\text { D. nenus Dogiel et } \\
\text { Bychowsky, } 1934\end{array}$ & 0.1 & & 0.2 & & & & & & & & \\
\hline $\begin{array}{c}\text { D. difformis } \\
\text { Wagener, } 1857\end{array}$ & & & & & & & & 0.06 & & & \\
\hline $\begin{array}{c}\text { D. chranilowi } \\
\text { Bychowsky, } 1936\end{array}$ & & 0.4 & & & & & & & & & \\
\hline $\begin{array}{c}\text { D. wunderi } \\
\text { Bychowsky, } 1931\end{array}$ & 1.0 & & & & & & & & & & \\
\hline $\begin{array}{c}\text { D. zandti } \\
\text { Bychowsky, } 1933\end{array}$ & 1.0 & & & & & & & & & & \\
\hline $\begin{array}{c}\text { D. ramulosus } \\
\text { Malewitzkaja, } 1941\end{array}$ & & & & & & & 17.0 & & & & \\
\hline $\begin{array}{l}\text { D. crusifer Wagener, } \\
1857\end{array}$ & & & & 0.6 & & & & & & & \\
\hline $\begin{array}{l}\text { D. cornu Linstow, } \\
1878 \\
\end{array}$ & 32.6 & & 10.3 & 1.8 & & & & & & & \\
\hline $\begin{array}{l}\text { D. vastator Nybelin , } \\
1924\end{array}$ & & & & & & 17.0 & & & & & \\
\hline $\begin{array}{l}\text { D. extensus Mueller } \\
\text { et Van Cleave, } 1932\end{array}$ & & & & & & 8.8 & & & & & \\
\hline $\begin{array}{l}\text { Dactylogyrus } \\
\text { sp. } \\
\end{array}$ & & & & & 0.04 & & & & & & \\
\hline $\begin{array}{c}\text { Ancyrocephalus } \\
\text { paradoxus Creplin, } \\
1839\end{array}$ & & & & & & & & & & 13.9 & 4.0 \\
\hline $\begin{array}{c}\text { Tetraonchus } \\
\text { monenteron Dsesing, } \\
1858 \\
\end{array}$ & & & & & & & & & 16.6 & & \\
\hline $\begin{array}{c}\text { Girodactylus } \\
\text { parvicopula } \\
\text { Bechowsky, } 1933\end{array}$ & 1.2 & & 1.1 & 0.3 & & & & & & & \\
\hline $\begin{array}{c}\text { G.elegans Nordm., } \\
1832 \\
\end{array}$ & & & & & & & & 0.4 & & & \\
\hline $\begin{array}{l}\text { G. lusiopercae } \\
\text { Gussev, } 1962 \\
\end{array}$ & & & & & & & & & & 0.6 & \\
\hline Girodactylus sp. & & & & & 0.5 & & 0.4 & & & & \\
\hline
\end{tabular}




\begin{tabular}{|c|c|c|c|c|c|c|c|c|c|c|c|}
\hline $\begin{array}{c}\text { Diplozoon } \\
\text { paradoxum Nordm., } \\
1832\end{array}$ & 2.0 & & & & & & & & & & \\
\hline $\begin{array}{c}\text { D. homoion } \\
\text { Bychowsky et } \\
\text { Nagibina, } 1959 \\
\end{array}$ & & & & 0.2 & & & & & & & \\
\hline $\begin{array}{c}\text { D. megan } \\
\text { Bychowsky et } \\
\text { Nagibina, } 1959\end{array}$ & & & & & & & 0.4 & & & & \\
\hline $\begin{array}{c}\text { D. nagibinae Glasser, } \\
1965\end{array}$ & & 2.4 & & & & & & & & & \\
\hline \multicolumn{12}{|c|}{ Cestoda } \\
\hline $\begin{array}{l}\text { Caryophyllaeus } \\
\text { laticeps P., } 1757\end{array}$ & 0.4 & & & & & & & & & & \\
\hline Caryophyllaeus sp. & & & 0.4 & 0.1 & & & & & & & \\
\hline $\begin{array}{c}\text { Triaenophorus } \\
\text { crassus } \text { Forel, } 1880\end{array}$ & & & & & & & & & 3.8 & & \\
\hline $\begin{array}{c}\text { Bothriosephalus } \\
\text { dowkongensus Yehn, } \\
1955 \\
\end{array}$ & & & & & & 16.2 & & & & & \\
\hline $\begin{array}{c}\text { Proteocephalus } \\
\text { percae Muller, } 1786\end{array}$ & & & & & & & & & & & 6.6 \\
\hline $\begin{array}{c}\text { P. torulosus Batsch, } \\
1786 \\
\end{array}$ & & & & 0.1 & & & 2.9 & & & & \\
\hline $\begin{array}{c}\text { P. esocis Schneider, } \\
1905 \\
\end{array}$ & & & & & & & & & 6.6 & & \\
\hline \multicolumn{12}{|c|}{ Nematoda } \\
\hline $\begin{array}{c}\text { Camallanus lacus } \\
\text { Zoega, } 1776\end{array}$ & & & & & & & & & & 5.5 & 8.0 \\
\hline $\begin{array}{c}\text { Rhaphidascaris acus } \\
\text { Bloch, } 1779 \\
\end{array}$ & & 3.6 & & 0.1 & & & & & 8.3 & & \\
\hline $\begin{array}{l}\text { Nematoda larva gen. } \\
\text { sp. }\end{array}$ & 5.2 & & & 0.6 & & & & & & & \\
\hline \multicolumn{12}{|c|}{ Acanthocephala } \\
\hline $\begin{array}{l}\text { Acanthocephalus } \\
\text { lucas Muller, } 1776\end{array}$ & & & & & & & & & 7.2 & 3.1 & \\
\hline \multicolumn{12}{|c|}{ Hirudines } \\
\hline $\begin{array}{c}\text { Piscicola geometra } \\
\text { L., } 1761\end{array}$ & & & & & & & & & & 2.7 & \\
\hline \multicolumn{12}{|c|}{ Crustacea } \\
\hline $\begin{array}{l}\text { Achtares percarum } \\
\text { Nordm., } 1832\end{array}$ & & & & & & & & & & 2.7 & \\
\hline $\begin{array}{l}\text { Ergasilus sieboldi } \\
\text { Nordm., } 1832\end{array}$ & 0.5 & 7.0 & & 0.8 & & & & 2.4 & 13.3 & & \\
\hline $\begin{array}{c}\text { Argulus folisceus L., } \\
1758\end{array}$ & 1.8 & 4.0 & 2.4 & 2.4 & 3.2 & 18.5 & 5.4 & 3.7 & 6.6 & 5.2 & 5.6 \\
\hline \multicolumn{12}{|c|}{ Mollusca } \\
\hline Glochidium sp. & 0.2 & 3.6 & 0.2 & 0.2 & 1.0 & 2.0 & 0.2 & 1.0 & & 1.4 & 0.5 \\
\hline
\end{tabular}

In juveniles of ram and pike, single specimens of Azygia lucii were found, which are infected by ingestion of free cercariae in plankton.

At the stage of metacercariae, 13 species of trematodes were found. The adult forms of most of them parasitize in birds, two species - in predatory fish. The most common types of metacercariae in juvenile fish from the lower reaches of the Dnieper are, according to our research, 
Posthodiplostomum cuticola, Diplostomum spathaceum, Diplostomum elevatum, Brucephalus polymorphus, Rhipidostomum illense. They were found in almost all examined fish with an intensity of infection from single specimens to 20-30 specimens per fish specimen. Infection of fish with metacercariae is carried out by active introduction of cercariae into the body of fish.

We found that in the shallow areas of the surveyed water area in fish larvae, the invasion of trematodes by metacercariae was $1.7 \%$ higher than in deep-water areas. In our opinion, the proximity to mollusks, the intermediate hosts of trematodes, and the good heating of the water promotes the maturation and activity of cercariae.

As the fish grow, the degree of their infestation with metacercariae increases, and the process of accumulation of metacercariae in the fish organism also occurs, which in turn leads to an increase in the intensity of invasion. The largest number of species of metacercariae was found in fry of bream (seven species), roach and rudd (five species each); in other fish species, from one to three species of metacercariae were found.

The species composition of monogeneans in fish larvae and fry includes 24 species. Most of the monogeneans found belong to the genus Dactylogyrus (14 species), Gyrodactylus (four species), Diplozoon (four species), and one species each was found from the genera Ancyrocephalus and Tetraonohus.

The timing of infection of fish of younger age groups with monogenes is mainly determined by the developmental characteristics of each type of parasite, the timing of the appearance of a free-swimming larva. For the first time, these helminths appear in fish larvae. From June, an intensive colonization of gill petals by representatives of the genus Dactylogyrus begins and an increase in the extensiveness of invasion (up to 29.9 and $44.4 \%$ ). Moreover, the intensity of invasion was insignificant in almost all cases. Representatives of the genus Diplozoon appear in fish fry in late July - September. Mostly immature parasites were found, and only in a few cases were adult worms found.

Monogeneans, in addition to species specificity, also have age specificity. In juvenile individuals of many fish species (bream, roach, silver bream, rudd), there are such species of monogeneans, which were very rarely or not at all detected by us in adult fish. Thus, in larvae and fry of roach, Dactylogyrus nanus appears earlier than in other fish. At the same time, Dactylogyrus crucif are specific monogenes for adult fish of this species. Dactylogyrus zandti and Dactylogyrus cornu are characteristic of juvenile bream, while Dactylogyrus wunderi and 
Dactylogyrus auriculatue are usually parasites in bream that have reached the commercial level.

Single specimens of the latter species appear in bream fry only by autumn. As a rule, monogeneans removed from juvenile fish are smaller than worms of the same species from adult fish. Thus, on juveniles of different fish species, there are "juvenile" forms of various species of monogeneans. Apparently, this phenomenon should be considered as a kind of adaptation to certain conditions of existence of gill flukes on juvenile fish.

We found seven cestode species in the larvae and fry of the studied fish. For the first time, these helminths appear in fish larvae at the prelarva stage. These are representatives of the genera Proteocephalus, Triaenophorus and Bothriocephalus, which are infected through intermediate hosts - crustaceans of the genera Acanthocyclops, Cyclops, Mesocyclops, etc. The maximum infection with cestodes was noted in October. In August - September, during the transition of juvenile fish to partial feeding on benthos, single specimens of cloves appear in the intestines of fish, the infection with which passes through the oligochaetes. The nematodes in our collections include three species of Rhaphidascaris acus and Camallanus lacustris, which are infected when fish feed on the copepods Cyclops leuckarti, Cyclops strenuus, etc., and are also represented by nematode larvae, the species of which we could not determine.

Three species of parasitic crustaceans (Achteres percarum, Ergasillus sieboldi, Argulus foliaceus) were found in $4.5 \%$ of juvenile fish in single specimens. Parasitic crustaceans usually appear in fish larvae at the earliest stages of their development. Argulus foliaceus, most often found in shallow, heavily overgrown and well-warmed parts of the reservoir. Ergasillus sieboldi usually appeared in fish larvae when they left the coastal overgrown areas to deeper and less overgrown areas of the reservoir. Representatives of worms, leeches and mollusks were found in one species and in single specimens.

Our research is confirmed by the analysis of the parasite fauna in other water bodies. The influence of climate and fish habitat on the distribution of parasitic fauna is clearly traced in the works of various authors who described water bodies of different climatic zones. In Lake Manzala, Egypt, the parasitic fish community of the genus Tilapia consisted of 12 species, one protozoan (Trichodina nigra), eight species of monogeneans (Ichtyodogyrus arthracanthus, Cichlidogyrus 
aegypticus, Cichlidogyrus sclerosus, Cichlidarum), one acanthocephalus (Acanthogyrus tilapiae), and two crustacean species'.

Twenty parasitic nematode species belonging to the species Ascaridoidea, Camallanoidea, Cosmocercoidea, Dioctophymatoidea, Habronematoidea, Oxyuroidea, Seuratoidea and Thelazioidea were collected from freshwater fish in the Democratic Republic of the Congo Basin and the Congo $\operatorname{Basin}^{10}$.

As a result of a parasitological survey of 12 most abundant fish species in the lakes of Belarus, 27 species of parasites belonging to 7 classes were recorded: Crustacea, Monogenea, Hirundinea, Nematoda, Acanthocephala, Trematoda, Cestoda. In addition, in the surveyed area, fish have 2 species of ciliated ciliates belonging to the Ciliophora type ${ }^{11}$.

In addition, relatively recently, new data on fish parasites in the basins of the Severnaya Dvina, Mezen, and Pechora rivers have appeared $^{12}$. In the water bodies of the Astrakhan Region, there were sanitary parasites represented by eight species of three taxonomic groups: nematodes and trematodes.

As Çolak H.S. points out ${ }^{13}$ [18] 33 parasite species were found in 10 fish species living in Lake Sygyrdzhy, Turkey. Of these parasites, 18 are monogenes, 5 species of trematodes, 3 species of cestodes, 3 species of worms, 3 are nematodes, and 1 species of Mollusca: Bivalvia (glochidia).

In reservoirs from the vicinity of Kiev, eight fish species (bream, pike perch, char, pike, perch, crucian carp, roach) were examined for the presence of trypanosomes. The prevalence of infection ranged from $24 \%$ in the freshwater bream Abramis brama Linnaeus to $100 \%$ in the char Cobitis taenia Linnaeus. Northern pike Esox lucius Linnaeus, freshwater

${ }^{9}$ Ibrahim, M.M. (2012). Variation in parasite infracommunies of Tilapia zilliiin relation to some biotic and abiotic factors. International Journal of Zoological Research, 8(2), pp. 59-60

${ }^{10}$ Moravec, F., Jirků, M. (2017). Some nematodes from freshwater fishes in central Africa. Folia Parasitologica. 64: 033. p. 3. doi: 10.14411/fp.2017.033.

11 Дегтярик С.M. Паразитозы рыбы, распространенные в естественных водоемах и прудовых хозяйствах Беларуси. Минск: Весі націянальныя акадъеміі наук Беларусі, серыя аграрных наук. 2006. № 5. С. 163.

12 Доровских Г. Н. Зоогеография паразитов рыб главных рек СевероВостока Европы : монография. Сыктывкар : Изд-во Сыктывкарского государственного университета, 2011. 12 с.

13 Çolak, H. S. (2013). Metazoan parasites of fish species from Lake Siğırcı (Edirne, Turkey). Turkish Journal of Veterinary and Animal Sciences, 37, pp. 200-205. 
bream, barbed char and European perch Perca fluviatilis Linnaeus, were simultaneously infected with two different trypanosome species ${ }^{14}$.

An important problem is the appearance in the hydroecosystems of Ukraine of introduced fish parasites from the river basins of the Far East and China. The list of parasites includes 102 names, including protozoa33 species, monogeneans - 17, cestodes - 12, trematodes - 16, nematodes -4 , leeches -2 , worms -9 , molluscs -1 and crustaceans 8 species $^{15}$.

\section{CONCLUSIONS}

Based on our materials and literature data, it can be noted that the parasite fauna of juvenile fish in the first year of life consists mainly of specific species of parasites. The species composition of the parasitic fauna of juvenile fish is more specific for a particular water body than for a certain type of fish and depends on the parasitological situation of a given water body.

Different species of juvenile fish of the same water body often have many common parasites. This is primarily due to the similar lifestyle and nutrition of fish at the early stages of their development. A similar range of nutrition for juvenile fish (planktonic crustaceans) also contributes to infection with the same types of intestinal forms of helminths.

In the weakly flowing areas of the water area, in juveniles of 11 species of the surveyed fish, we found the carp beetle Argulus foliaceus, in 10 species of fish metacercariae of the trematodes Diplostomum spathaceum and Posthodiplostomum cuticola, in 9 species - Ichthyophtirius polyorphuphillus multifillis, in 7 species metacercariae. In other parts of the surveyed water area, the set of parasites for certain fish species is completely different. Metacercariae Diplostomum spathaceum and Posthodiplostomum cuticola were found in larvae and fry of 9 fish species, and Bucephalus polymorphus and Myxobolus dispar in 7 fish species.

14 Grybchuk-Ieremenko, A., Losev, A., Kostygov, A., Lukeš, J., \& Yurchenko, V. (2014). High prevalence of trypanosome co-infections in freshwater fishes. Folia Parasitologica, 61(6), p. 496. DOI: 10.14411/fp.2014.064

15 Давыдов О.Н., Куровская Л.Я., Темниханов Ю.Д., Неборачек С.И. Паразиты некоторых инвазийных рыб пресных водоемов Украины. Гидробиологический журнал. 2011. Т. 47, № 6. С. 79-86. 
It should be noted that we did not study parasitic ciliates, although they were richly represented in the collections.

\section{SUMMARY}

Global climate change on our planet against the background of growing anthropogenic pollution has become one of the decisive environmental problems of our time. Hydroecosystems are no exception, the level of anthropogenic load on which is constantly growing.

At the moment, various kinds of toxicants have become an integral factor of the external environment for aquatic organisms, including in the reservoirs of the lower Dnieper. As a result of such progressive pollution within this water area, a rather critical ichthyopathological situation has developed. This is due to the fact that the resistance of fish to the action of parasites is determined not only by their morphological and other qualitative indicators, but also by the physiological state of the fish, and also depends on the level of negative impact on the fish of critical environmental factors.

In this case, the dynamic processes of development of the parasite fauna can directly influence the composition of the ichthyofauna, including its industrial part.

Changes in the composition of the parzitofauna caused by climatic and ecological factors necessitate constant monitoring.

This became the purpose of the research, the results of which formed the basis of the article. The main task of the research was to conduct an ecological-faunistic analysis of parasites of larvae and fry of the main commercial fish species in the lower reaches of the Dnieper, to determine the degree of development of the parasite fauna.

Selection of ichthyological and ichthyopathological samples in 20182020 carried out in the lower reaches of the Dnieper. Epizootic and parasitological studies were carried out in accordance with the known recommendations.

Of the total number of young fish surveyed, one thousand eight hundred and twenty-two were infected with parasites.

The found parasites belong to nine systematic groups: simple $28.3 \%$; trematodes $-31.9 \%$; monogeneans $-16.9 \%$; cestodes $-3.0 \%$; nematodes $-1.3 \%$; scrapers $-0.5 \%$; leeches $-0.03 \%$; crustaceans -4.5 ; shellfish -0.5 . 
In weak-flowing areas of the water area, in juveniles of 11 species of fish we examined, we found Argulus foliaceus, metacercariae of trematodes Diplostomum spathaceum and Posthodiplostomum cuticola in 10 fish species, Ichtyophthirius polyphyphilus multiphillis and 7 species - metacercariae.

In other parts of the surveyed water area, the set of parasites for certain fish species is completely different. Metacercariae Diplostomum spathaceum and Posthodiplostomum cuticola were found in larvae and fry of 9 fish species, and Bucephalus polymorphus and Myxobolus dispar in 7 fish species.

Research results suggest outbreaks of bacterial and parasitic diseases in fish in the coming years, which can cause significant economic damage to the fish industry in the lower reaches of the Dnieper.

\section{References}

1. Беэр С.А. Роль патогенности паразитов в эволюции органического мира. Успехи общей паразитологи. 2003. Т. 44. C. $65-80$.

2. Buchmann K. An introduction to practical methods in fish parasitology. Classical and molecular techniques. Denmark, Frederiksberg: Biofolia Press, 2007. 130 p.

3. Grybchuk-Ieremenko, A., Losev, A., Kostygov, A.Y., Lukeš, J., \& Yurchenko, V. (2014). High prevalence of trypanosome co-infections in freshwater fishes. Folia Parasitologica, 61(6), pp. 495-504. DOI: 10.14411/fp.2014.064.

4. Hubanova, N., Horchanok, A., Novitskii, R., Sapronova, V., Kuzmenko, O., Grynevych, N.,. Prisjazhnjuk, N, Lieshchova, M., Slobodeniuk, O., Demyanyuk, O. Accumulation of radionuclides in Dnipro reservoir fish. Ukrainian Journal of Ecology, 2019, 9(2), pp. 227-231.

5. Давыдов О.Н., Куровская Л.Я., Темниханов Ю.Д., Неборачек С.И. Паразиты некоторых инвазийных рыб пресных водоемов Украины. Гидробиологический журнал. 2011. Т. 47, № 6. С. $76-89$.

6. Дегтярик, С.М. Паразитозы рыбы, распространенные в естественных водоемах и прудовых хозяйствах Беларуси. Минск: Весі націянальныя акадъеміі наук Беларусі, серыя аграрных наук. 2006. № 5. C. 162-164. 
7. Доровских Г.Н. Зоогеография паразитов рыб главных рек Северо-Востока Европы : монография. Сыктывкар : Изд-во Сыктывкарского государственного университета, 2011. 142 с.

8. Iyaji, F., Etim, L., \& Eyo, J. (2010). Parasite assemblages in fish hosts. Bio-Research, 7(2), pp. 561-570.

9. Ibrahim, M.M. (2012). Variation in parasite infracommunies of Tilapia zilliiin relation to some biotic and abiotic factors. International Journal of Zoological Research, 8(2), pp. 59-70.

10. Kvach Y., Drobiniak O., Kutsokon Y., Hoch I. (2013). The parasites of the invasive Chinese sleeper Perccottus glenii (fam. Odontobutidae), with the first report of Nippotaenia mogurndae in Ukraine. Knowledge and Management of Aquatic Ecosystems. № 409. Pp. 1-11

11. Çolak, H. S. (2013). Metazoan parasites of fish species from Lake Sığırcı (Edirne, Turkey). Turkish Journal of Veterinary and Animal Sciences, 37, pp. 200-205.

12.Коблицкая А.Ф. Определитель молоди пресноводных рыб. Москва: Легкая промышленность, 1981. 208 с.

13. Корнюшин В.В., Лосев А.А., Ивасюк Ю.С., Лысенко В.Н. (2019). Гельминты пресноводных и проходных рыб Украины. Цестоды и цестодарии. Киев : Институт зоологии им. И.И. Шмальгаузена НАН Украины, 2019. С. 1-30. DOI: 10.13140 / RG.2.2.33732.88967.

14. Matvjenko N, Buchatsky L, Rud Yu. Methodological recommendations on laboratory diagnosis of fish diseases. Kyiv, IRG NAAN. 2009;19 p.

15. Moravec, F., Jirků, M. (2017). Some nematodes from freshwater fishes in central Africa. Folia Parasitologica. 64:033. Pp. 1-39. doi: 10.14411/fp.2017.033.

16.Національна доповідь про стан навколишнього середовища Херсонської області. Київ : Вид. Раєвського, 2018. 60 с.

17.Пилипенко Ю.В., Оліфіренко В.В., Корнієнко В.О., Поліщук В.С, Довбиш О.Е., Лобанов I.А. Екологічні передумови раціонального ведення рибного господарства Дніпровсько-Бузької гирлової області. Херсон : Видавець Грінь Д.МС., 2013. 190 с.

18. Пилипенко Ю.В., Шевченко П.Г., Цедик В.В., Корнієнко В.О. Методи іхтіологічних досліджень : Навчальний посібник. Херсон : Олді-Плюс, 2017. 432 с. 
19.Fedonenko, O., Yesipova, N., Sharamok,T. The accumulation of heavy metals and cytometric characteristics features of red blood cells in different ages of carp fish from Zaporozhian Reservoir. International Letters of Natural Sciences, 2016. Vol. 53, pp. 72-79. https://doi.org/10.18052/www.scipress.com/ILNS.53.72.

\section{Information about the authors: Olifirenko Vitalii Vitaliiovych,} Candidate of Veterinary Sciences, Associate Professor at the Department of Ecology and Sustainable Development named after professor Yu. V. Pilipenko Kherson State Agrarian and Economic University 23, Stritenska str., Kherson, 73006, Ukraine

Korniienko Volodymyr Oleksandrovych, Candidate of Agricultural Sciences, Associate Professor at the Department of Aquatic Bioresources and Aquaculture Kherson State Agrarian and Economic University 23, Stritenska str., Kherson, 73006, Ukraine 